\title{
Correlation Equations of CBR with Index Properties of Soil in the City of Piura
}

\author{
William Araujo, Civil Engineer ${ }^{1}$, Gaby Ruiz, Master of Civil Engineering ${ }^{2}$, \\ ${ }^{1}$ Universidad de Piura, Peru,william.araujo@udep.pe \\ ${ }^{2}$ Universidad de Piura, Peru, gaby.ruiz@udep.pe
}

Abstract- The California Bearing Ratio (CBR) is a method for the
relative quality of the subgrade, subbase and base of a pavement
evaluation throughout an essay on the field or laboratory and also
pavement design. The most common is CBR soaked, nevertheless,
obtaining its value is expensive and time consuming. The main
objective of this research is correlating CBR with some index
properties of soils of easy evaluation: percentage of gravel (G),
percentage of sand (S), percentage of fine (F), liquid limit (LL),
plastic limit (PL), plastic index (PI), optimal moisture content
(OMC) and maximum dry density (MDD); to propose an alternative
method to obtain the CBR value. For this research, simple and
multiple correlation using Microsoft Excel was applied in a total of
75 samples of granular and clayed soils from Piura city, obtained
from a local laboratory's records.
Keywords-- California Bearing Ratio, Liquid Limit, Plastic Limit, Maximum Dry Density.

Digital Object Identifier (DOI):

http://dx.doi.org/10.18687/LACCEI2016.1.1.029

ISBN: 978-0-9822896-9-3

ISSN: $2414-6390$

$14^{\text {th }}$ LACCEI International Multi-Conference for Engineering, Education, and Technology: "Engineering Innovations for Global Sustainability", 20-22 July 2016, San José, Costa Rica. 


\title{
Correlation Equations of CBR with Index Properties of Soil in the City of Piura
}

\author{
William Araujo, Civil Engineer ${ }^{1}$, Gaby Ruiz, Master of Civil Engineering ${ }^{2}$, \\ ${ }^{1}$ Universidad de Piura, Peru, william.araujo@udep.pe \\ ${ }^{2}$ Universidad de Piura, Peru, gaby.ruiz@udep.pe
}

\begin{abstract}
The California Bearing Ratio (CBR) is a method for the relative quality of the subgrade, subbase and base of a pavement evaluation throughout an essay on the field or laboratory and also pavement design. The most common is CBR soaked, nevertheless, obtaining its value is expensive and time consuming. The main objective of this research is correlating $C B R$ with some index properties of soils of easy evaluation: percentage of gravel $(G)$, percentage of sand (S), percentage of fine (F), liquid limit (LL), plastic limit (PL), plastic index (PI), optimal moisture content (OMC) and maximum dry density (MDD); to propose an alternative method to obtain the CBR value. For this research, simple and multiple correlation using Microsoft Excel was applied in a total of 75 samples of granular and clayed soils from Piura city, obtained from a local laboratory's records.
\end{abstract}

Keywords-- California Bearing Ratio, Liquid Limit, Plastic Limit, Maximum Dry Density.

\section{INTRODUCTION}

In Peru as in other countries, CBR value is extensively used to design pavements. To overcome cost and time consumption in the execution of tests there have been several attempts to correlate CBR with index properties of soil [1-7]. The index properties evaluated in those studies were the gravel percentage $(\mathrm{G})$, percentage of sand $(\mathrm{S})$, and percentage of fines: silts and clays (F), liquid limit (LL), plastic limit (PL) plasticity index (PI), maximum dry density (MDD) and maximum moisture content (OMC). These are easily compared with CBR soaked (about time and cost).

Thus, a value can be predicted by an equation of CBR in terms of these parameters, being a more economical and faster method than conventional. According to Yildirim and Gunaydin [8] this equation can be used to do a first estimation for a project in conceptual phase but never will replace the real test results.

\section{DATA DESCRIPTION}

A. Nature of the data

A sample of 75 values from a local laboratory's records was used. The sample was selected from the samples recorded with complete information about gravel content (0 and 68\%), percentage of sand ( 0 to $83 \%$ ) the content of fines (clay and silt) (7 to 98\%), liquid limit (15 to $75 \%$ ), plastic limit (13 to $26 \%$ ), the plasticity index (1 to $49 \%$ ), maximum dry density (1.62 to $2.29 \mathrm{~g} / \mathrm{cm} 3$ ), the optimum moisture content (4.5 to $19.2 \%$ ) and CBR values (1 to $81 \%$ ). The three locations studied were: Piura city, where the predominant soils were clay, silty and clayey sands and low plasticity silts; Paita Province, with loamy and clayey soils;
Morropón Province, where the soils consist of silty and clayey sands and gravel. The highest concentration of data is located in the urban area of the city of Piura (See Fig. 1).

USCS identification of the soils was: silty clays (CM), clays of high plasticity $(\mathrm{CH})$, clays of low plasticity (CL), silts of high plasticity $(\mathrm{MH})$ and low plasticity silt (ML) and well graded gravel (GW), clayey gravel (GC), silty gravel (GM), clayey sands (SC) and silty sands (SM).

The data was selected from soil samples whose laboratory tests consisted of: sieve analysis (G, S, F), consistency limit (LL, PL, IP) and compaction properties (MDD, OMC). The USCS soil's classification was used for this research.

$B$. Index properties of soil and their influences in $C B R$ value

Sieve Analysis: The percentage of gravel influences the CBR value depending on the shape of the particles. An angular particle has a greater linkage and greater shear strength, so soil will have a greater CBR value if there are no other influencing factors. The mineralogical origin of gravel probably influences the CBR value for hardness. Some aggregates are harder than others, for this reason they could have greater shear strength. In the Table I all the data used in this research is shown.

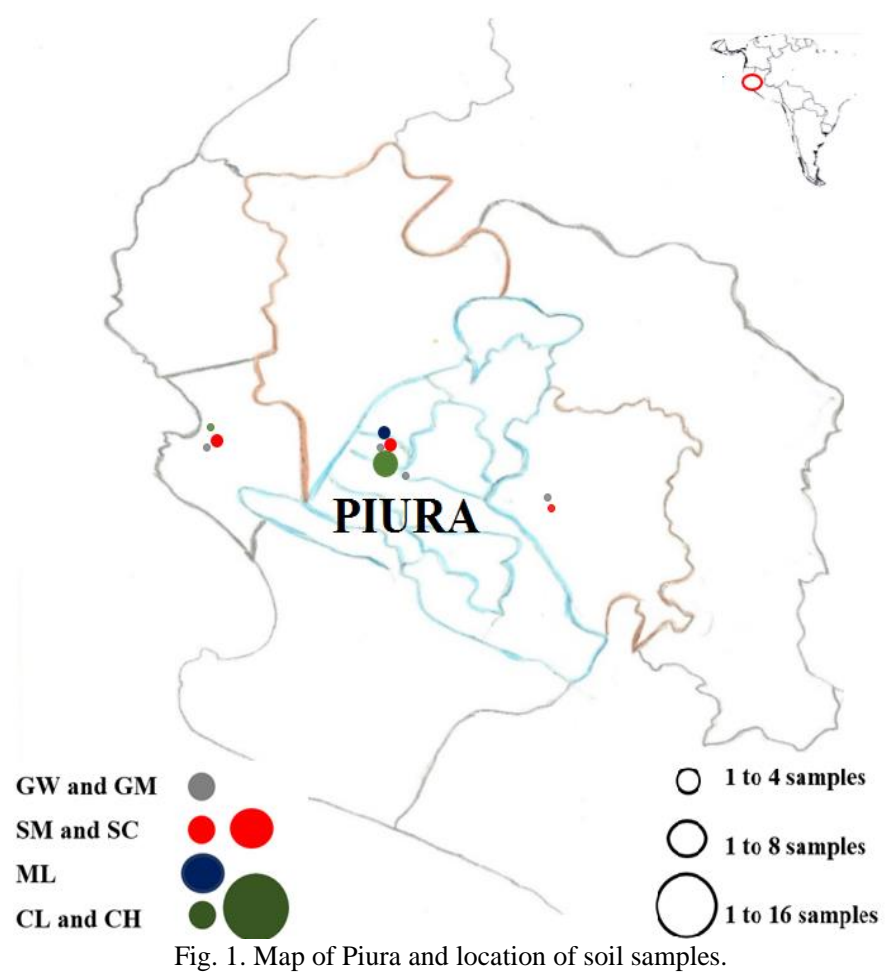

Fig. 1. Map of Piura and location of soil samples.

Digital Object Identifier (DOI): http://dx.doi.org/10.18687/LACCEI2016.1.1.029 ISBN: 978-0-9822896-9-3

ISSN: $2414-6390$

$14^{\text {th }}$ LACCEI International Multi-Conference for Engineering, Education and Technology: "Engineering Innovations for 
TABLE I

DATABASE USED OF SOIL SAMPLES OF PIURA

\begin{tabular}{|c|c|c|c|c|c|c|c|c|c|}
\hline G & $\mathbf{S}$ & $\mathbf{F}$ & $\mathbf{L L}$ & LP & IP & MDD & OMC & CBR & USCS \\
\hline 63 & 30 & 7 & 24 & 22 & 2 & 2.13 & 9 & 32 & GW \\
\hline 0 & 31 & 69 & 26 & 17 & 9 & 1.86 & 12.2 & 7 & ML \\
\hline 0 & 64 & 36 & 22 & 15 & 7 & 1.95 & 10.2 & 22 & ML \\
\hline 0 & 20 & 80 & 42 & 22 & 20 & 1.89 & 12.5 & 1 & $\mathrm{CH}$ \\
\hline 0 & 60 & 40 & 21 & 16 & 5 & 1.92 & 10.5 & 27 & ML \\
\hline 10 & 36 & 54 & 30 & 22 & 8 & 1.71 & 15 & 5 & ML \\
\hline 0 & 37 & 63 & 31 & 16 & 15 & 1.82 & 13 & 3 & $\mathrm{CL}$ \\
\hline 0 & 58 & 42 & 24 & 14 & 10 & 1.71 & 15.5 & 14 & ML \\
\hline 0 & 80 & 20 & 15 & 14 & 1 & 1.70 & 12 & 16 & SM \\
\hline 12 & 46 & 42 & 30 & 24 & 6 & 1.70 & 16 & 14 & ML \\
\hline 0 & 77 & 23 & 19 & 14 & 5 & 1.67 & 12 & 8 & SM \\
\hline 56 & 30 & 14 & 21 & 17 & 4 & 2.24 & 5.8 & 63 & GW \\
\hline 0 & 64 & 36 & 22 & 15 & 7 & 1.95 & 10.2 & 65 & ML \\
\hline 15 & 40 & 45 & 31 & 24 & 7 & 1.71 & 15.5 & 65 & ML \\
\hline 57 & 34 & 9 & 16 & 15 & 1 & 2.12 & 5.5 & 54 & GW \\
\hline 46 & 14 & 40 & 27 & 15 & 12 & 2.21 & 6.3 & 22 & $\mathrm{CL}$ \\
\hline 0 & 15 & 85 & 29 & 19 & 10 & 1.85 & 13 & 6 & $\mathrm{CL}$ \\
\hline 0 & 46 & 49 & 36 & 25 & 11 & 1.98 & 11.5 & 11 & $\mathrm{SC}$ \\
\hline 2 & 56 & 42 & 24 & 21 & 3 & 1.73 & 15 & 13 & SM \\
\hline 0 & 46 & 49 & 36 & 25 & 11 & 1.74 & 13 & 10 & $\mathrm{SC}$ \\
\hline 0 & 46 & 49 & 36 & 25 & 11 & 1.75 & 13 & 24 & $\mathrm{SC}$ \\
\hline 60 & 25 & 15 & 24 & 13 & 11 & 2.25 & 8 & 47 & GC \\
\hline 66 & 23 & 11 & 26 & 15 & 11 & 2.22 & 7 & 46 & $\mathrm{SC}$ \\
\hline 27 & 52 & 21 & 31 & 18 & 13 & 1.93 & 12 & 13 & $\mathrm{CL}$ \\
\hline 57 & 32 & 11 & 22 & 18 & 4 & 2.17 & 7 & 59 & GM \\
\hline 0 & 40 & 60 & 28 & 21 & 7 & 1.93 & 8 & 6 & CL-ML \\
\hline 0 & 57 & 43 & 20 & 17 & 3 & 1.87 & 12 & 19 & SM \\
\hline 0 & 39 & 17 & 34 & 16 & 18 & 2.10 & 7.3 & 17 & $\mathrm{SC}$ \\
\hline 0 & 5 & 95 & 75 & 26 & 49 & 1.62 & 19.2 & 5 & $\mathrm{CH}$ \\
\hline 0 & 72 & 28 & 27 & 17 & 10 & 1.87 & 13.2 & 20 & SM \\
\hline 0 & 43 & 57 & 39 & 15 & 24 & 1.87 & 13.4 & 7 & $\mathrm{CL}$ \\
\hline 0 & 73 & 27 & 28 & 19 & 9 & 1.88 & 12.6 & 25 & SM \\
\hline 0 & 47 & 53 & 35 & 16 & 19 & 1.91 & 13 & 6 & $\mathrm{CL}$ \\
\hline 0 & 55 & 45 & 28 & 17 & 11 & 2.00 & 12 & 7 & $\mathrm{SC}$ \\
\hline 0 & 58 & 42 & 31 & 17 & 14 & 1.93 & 12 & 18 & $\mathrm{SC}$ \\
\hline 0 & 49 & 51 & 22 & 20 & 2 & 1.66 & 12.3 & 15 & ML \\
\hline 2 & 49 & 49 & 24 & 17 & 7 & 2.00 & 11 & 13 & SC-SM \\
\hline 0 & 30 & 70 & 28 & 23 & 5 & 1.87 & 12.5 & 10 & CL-ML \\
\hline 0 & 23 & 77 & 39 & 17 & 22 & 1.95 & 13 & 2 & $\mathrm{CL}$ \\
\hline 0 & 64 & 36 & 23 & 17 & 6 & 1.62 & 12 & 17 & SM \\
\hline 0 & 83 & 17 & 20 & 15 & 5 & 1.80 & 10 & 19 & SC-SM \\
\hline 0 & 70 & 30 & 21 & 15 & 6 & 1.96 & 11.5 & 14 & SC-SM \\
\hline 2 & 32 & 66 & 32 & 17 & 15 & 1.93 & 12.3 & 5 & $\mathrm{CL}$ \\
\hline 3 & 28 & 69 & 26 & 20 & 6 & 1.92 & 12.5 & 5 & CL-ML \\
\hline 0 & 33 & 67 & 33 & 20 & 13 & 1.90 & 12 & 6 & $\mathrm{CL}$ \\
\hline 5 & 20 & 75 & 41 & 20 & 21 & 1.95 & 12.5 & 3 & $\mathrm{CL}$ \\
\hline 1 & 11 & 88 & 44 & 21 & 23 & 1.88 & 13 & 2 & $\mathrm{CL}$ \\
\hline 3 & 18 & 79 & 43 & 20 & 23 & 1.92 & 12.5 & 4 & $\mathrm{CL}$ \\
\hline 2 & 17 & 81 & 43 & 21 & 22 & 1.88 & 13.2 & 3 & $\mathrm{CL}$ \\
\hline 8 & 16 & 76 & 43 & 21 & 22 & 1.94 & 12.3 & 2 & $\mathrm{CL}$ \\
\hline 0 & 2 & 98 & 37 & 22 & 15 & 1.78 & 16.5 & 2 & $\mathrm{CL}$ \\
\hline 0 & 11 & 89 & 32 & 22 & 10 & 1.76 & 13 & 12 & $\mathrm{CL}$ \\
\hline 0 & 33 & 67 & 30 & 22 & 8 & 1.76 & 14 & 8 & CL \\
\hline 60 & 25 & 15 & 33 & 17 & 16 & 2.18 & 9.2 & 20 & $\mathrm{SC}$ \\
\hline 50 & 35 & 15 & 21 & 15 & 6 & 2.29 & 5.5 & 63 & GM \\
\hline 48 & 36 & 16 & 21 & 15 & 6 & 2.29 & 5.5 & 63 & GM \\
\hline 55 & 34 & 11 & 19 & 14 & 5 & 2.21 & 5.5 & 64 & GW \\
\hline
\end{tabular}

$14^{\text {th }}$ LACCEI International Multi-Conference for Engineering, Education and Technology: "Engineering Innovations for Global Sustainability"

July 20-22, 2016, San Jose, Costa Rica 
TABLE I (continued)

\begin{tabular}{|c|c|c|c|c|c|c|c|c|c|}
\hline G & $\mathbf{S}$ & $\mathbf{F}$ & LL & LP & IP & MDD & OMC & CBR & USCS \\
\hline 56 & 29 & 15 & 22 & 15 & 7 & 2.21 & 5.5 & 59 & SM \\
\hline 60 & 24 & 16 & 23 & 16 & 7 & 2.15 & 5 & 59 & SM \\
\hline 58 & 32 & 10 & 18 & 15 & 3 & 2.24 & 4.5 & 79 & GW \\
\hline 58 & 31 & 11 & 18 & 16 & 2 & 2.23 & 4.5 & 78 & GW \\
\hline 63 & 28 & 9 & 19 & 16 & 3 & 2.23 & 4.9 & 79 & GW \\
\hline 63 & 28 & 8 & 19 & 16 & 3 & 2.24 & 4.6 & 78 & GW \\
\hline 62 & 28 & 10 & 19 & 16 & 3 & 2.22 & 4.7 & 81 & GW \\
\hline 68 & 24 & 8 & 19 & 16 & 3 & 2.22 & 4.9 & 79 & GW \\
\hline 66 & 25 & 9 & 18 & 15 & 3 & 2.23 & 5 & 77 & GW \\
\hline 61 & 29 & 10 & 18 & 14 & 4 & 2.22 & 4.9 & 79 & GW \\
\hline 63 & 27 & 10 & 17 & 15 & 2 & 2.22 & 4.6 & 81 & $\mathrm{GW}$ \\
\hline 62 & 29 & 9 & 19 & 15 & 4 & 2.22 & 4.6 & 81 & $\mathrm{GW}$ \\
\hline 17 & 52 & 31 & 16 & 15 & 1 & 2.10 & 8.5 & 20 & $\mathrm{SM}$ \\
\hline 55 & 34 & 11 & 27 & 13 & 14 & 2.13 & 6 & 31 & $\mathrm{SC}$ \\
\hline 50 & 34 & 16 & 24 & 20 & 4 & 2.08 & 9 & 34 & GM \\
\hline 0 & 52 & 48 & 48 & 25 & 23 & 1.87 & 12 & 19 & SM \\
\hline 0 & 63 & 37 & 38 & 35 & 3 & 1.62 & 12 & 17 & SM \\
\hline 0 & 41 & 59 & 51 & 29 & 22 & 1.87 & 13.4 & 7 & $\mathrm{MH}$ \\
\hline
\end{tabular}

The most influential parameter of CBR value could be the content of gravel. As the concept of CBR was established having a pattern similar to crushed stone, it can be expected that the greater the number of gravel, the higher CBR value obtained. The correlation between $\mathrm{G}$ and CBR will probably be good.

The percentage of sand also has some influence on the CBR value. Soils with higher sand content have a more rigid behavior and probably more resistance. However, a larger content of sand means a lower content of gravel, which would result in a lower CBR value. Then, it can be said that the sand content analyzed individually is irrelevant for predicting the CBR value. The correlation between $\mathrm{S}$ and CBR will probably be poor.

The percentage of fines gives strength and stability to the soil. These parameters will be reflected in the limits of consistency which are reflected in the moisture content, void ratio and pore pressure, influencing soil shear strength and consequently to the CBR value. The correlation between $\mathrm{F}$ and CBR will probably be good and inverse.

Consistency Limits: All consistency limits (Plastic Limit, Liquid Limit and Plasticity index) are moisture content based, so if there is greater moisture content, there will be a worse CBR value. But, even with the values of Consistency Limits, their influence is limited to the content of fines (F) in the soil. The correlation between PL, LL and PI with CBR individually, will probably be poor.

Maximum Dry Density: If a soil is dense, their particles will be more united. Consequently, a denser soil increases soil strength and also theCBR value. The correlation between MDD and CBR will probably be good.

Optimum Moisture Content: The influence of this parameter with the $\mathrm{CBR}$ is that the degree of saturation will change soil strength, producing different CBR values for the same soil. A dry soil will have higher strength than the same soil with higher moisture content. According to ASTM D 1883 07 [1] when the test is performed with immersion (saturated during 4 days), it should be removed, leaving the specimen to drain water for 15 minutes before testing. During this phase the degree of saturation of the soil can be changed, increasing the suction and generating different CBR values in a same sample of the same soil [9]. The correlation between OMC and CBR will probably be good but inverse.

\section{Correlation from others researches}

Most research shows that MDD and OMC are the best correlation [4] [5] [6]. Patel [5] speculates that LL and LP have a poor correlation. Yildirim and Guanaydim [8] showed in a simple lineal correlation that $\mathrm{G}$ is the best correlation with a coefficient of determination (R2) of 0.86 .

Some researchers used clayed soils with CBR values between $1 \%$ and $6 \%$ and samples of less than 25 units. This research has a sample of 75 soils (fines and course) with CBR values between $1 \%$ and $81 \%$. In this wider range, this research tries to validate a lineal model.

\section{SIMPLE CORRELATION MODEL}

\section{A. Regression Analysis}

Each parameter was correlated with CBR value. The regression coefficient $(\mathrm{R})$ and the coefficient of determination (R2) were evaluated in order to obtain the goodness of fit of the regression, a measuring of linear association degree and rapprochement between the estimated and observed value.

This research's simple regression models were evaluated using Microsoft Excel because this software is good enough to offer good estimating [4-5].

$14^{\text {th }}$ LACCEI International Multi-Conference for Engineering, Education and Technology: "Engineering Innovations for Global Sustainability" 
Eight models with simple linear regression analysis were proposed to describe the influence of each index properties of soil individually with the value of the subgrade soaked CBR.

Models proposed were:

Model 1: G vs CBR

Model 2: $S$ vs CBR

Model 3: F vs CBR

Model 4: LL vs CBR

Model 5: LP vs CBR

Model 6: IP vs CBR

Model 7: MDD vs CBR

Model 8: OMC vs CBR

The equations of correlation using simple linear regression are summarized in Table II. The statistical parameters indicate that models 1 and 8 provide the best simple linear correlation with highest values of R and R2.

Model 1 was plotted in Fig. 2 and Model 8 in Fig. 3. It can be observed that there is a clear linear trend between both parameters. In Fig. 3, the CBR value was plotted against the optimum moisture content required in the soil to achieve the maximum dry density. As CBR value cannot be negative, the graphic OMC vs CBR is limited by CBR values equal to 0 . For values from 4 to $16 \%$ of OMC, the CBR value decreases to zero or very close.

Although these models have good correlation values, they are not suitable for certain types of soils, such as clay. According to the analysis, the equations are more applicable to gravelly soils. Although it may be applicable to gravelly soils, the standard deviation is very high in all of the proposed models. This would be an indicator that the linear regression can't generate a model that is sufficiently close to the data; it can be conducted a better research using an exponential correlation model.

\section{B. Residue Analysis for SLRA}

It was done a residue analysis to validate models of simple correlations obtained. The correlation between two variables can be high even though the relationship between both is strongly nonlinear [10]. The residue analysis evaluates whether the linear regression model is suitable.

TABLE II

EQUATIONS OF CORRELATION AND STATISTICAL PARAMETERS OBTAINED SLRA

\begin{tabular}{|c|c|c|c|}
\hline Model & Equation of correlation & $\mathrm{R}$ & $\mathrm{R} 2$ \\
\hline Model 1 & $\mathrm{CBR}=0.836 \mathrm{G}+11.378$ & 0.84 & 0.70 \\
\hline Model 2 & $\mathrm{CBR}=-0.203 \mathrm{~S}+36.687$ & 0.12 & 0.02 \\
\hline Model 3 & $\mathrm{CBR}=-0.785 \mathrm{~F}+60.185$ & 0.76 & 0.58 \\
\hline Model 4 & $\mathrm{CBR}=-1.588 \mathrm{LL}+73.734$ & 0.60 & 0.35 \\
\hline Model 5 & $\mathrm{CBR}=-2.796 \mathrm{LP}+80.146$ & 0.45 & 0.21 \\
\hline Model 6 & $\mathrm{CBR}=-1.778 \mathrm{IP}+46.502$ & 0.53 & 0.28 \\
\hline Model 7 & $\mathrm{CBR}=103.340 \mathrm{MDD}-174.710$ & 0.74 & 0.54 \\
\hline Model 8 & $\mathrm{CBR}=-6.055 \mathrm{OMC}+91.368$ & 0.81 & 0.66 \\
\hline
\end{tabular}

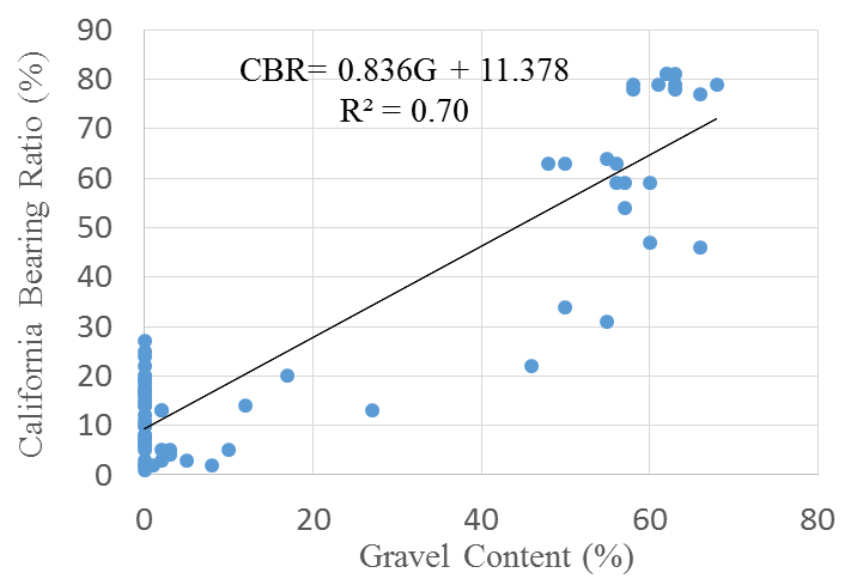

Fig. 2. SLRA model 1 of Grava Content vs California Bearing Ratio

In the Fig. 5, residues are small for CBR values between 0 and 20, and are higher for range of CBR value from 40 to 65 . This result reveals that this SLRA model 8 is adequate for estimating CBR values between 0 and 40 .

CBR values between 0 and 40 usually correspond to finegrained soils. In this case, the gravel content is not a determining factor in soil resistance compared with contents of plastics fine manifested as OMC. Usually the OMC is high when the fines content is also.

It also means that there is no possibility to develop a unique SLRA model for the estimation of CBR in a wide range of soils and only an individual model for fine grained soils can be developed using OMC values.

\section{MULTIPLE CORRELATION MODEL}

\section{A. Regression Analysis}

Multiple regression models were evaluated also using Microsoft Excel. In this research were made 246 combinations and 8 models with the highest values of $\mathrm{R}$ and $\mathrm{R} 2$ were chosen.

Multiple linear regression analysis (MLRA): In Table III, eight models with different combinations of index properties of soils with their soaked CBR subgrade soil of Piura were evaluated by multiple regression analysis with Microsoft Excel. The R and R2 statistical parameters are also showed.

The results show that the best model according to the $R$ and $\mathrm{R}^{2}$ is the model 7 of MLRA in the Table III where all soil parameters are considered.

It can mean that each (sieve analysis, consistent limit and compaction properties) is of importance to the soil CBR.

\section{B. Residue Analysis for MLRA}

In the figure 4 high residues are observed in ranges from 0 to 40 of CBR. This means that, unless a high correlation value was obtained, this model is not adequate for estimating CBR.

In the model 7 in a MLRA (view figure 6) are small residues for CBR values between 0 and 20 .

$14^{\text {th }}$ LACCEI International Multi-Conference for Engineering, Education and Technology: "Engineering Innovations for Global Sustainability" 


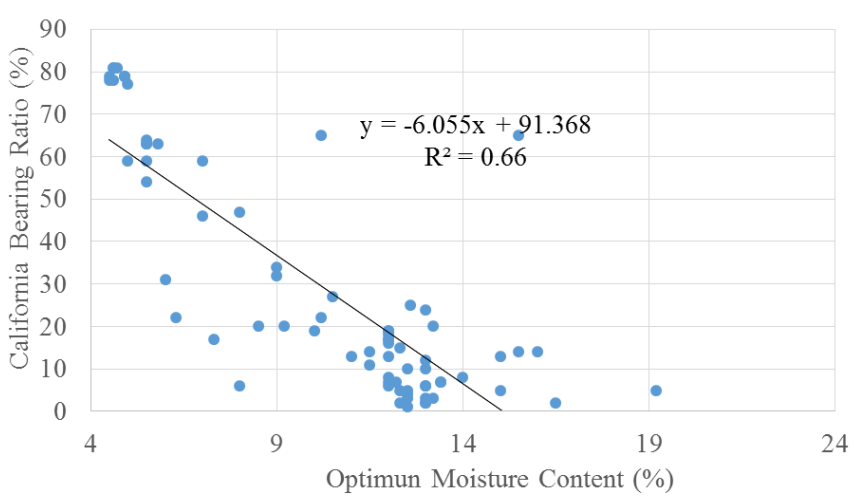

Fig. 3. SLRA model 8 of Optimum Moisture Content vs California Bearing Ratio

The linear models are not suitable to range of $\mathrm{CBR}$ value from this data $(1-81 \%)$. A local analysis is most appropriate for this case.

\section{E. Correlation of other existing models}

In the Table IV correlation models from others researchers are shown and also are compared to the multiple correlation model proposed in the present investigation, with statistical parameters as correlation coefficient $(\mathrm{R})$ and the coefficient of determination (R2). Most researchers restrict the model soil for type and different ranges of CBR. It can be noted that model 7 proposed in this research has an acceptable correlation coefficient compared with other researchers. Nevertheless, the other models have limitations in terms of soil type and CBR values range of application. Model 7 offers a good approximation for a wide range of soil types. Nevertheless, residue analysis estimates that this model is not suitable.

TABLE III

EQUATIONS OF CORRELATION AND STATISTICAL PARAMETERS OBTAINED MLRA

\begin{tabular}{|c|c|c|c|}
\hline Model & Equation of correlation & $\mathrm{R}$ & $\mathrm{R} 2$ \\
\hline $\begin{array}{c}\text { Model } \\
1 \\
\end{array}$ & $\mathrm{CBR}=0.526 \mathrm{G}-2.750 \mathrm{OMC}+46.145$ & 0.862 & 0.743 \\
\hline $\begin{array}{c}\text { Model } \\
2\end{array}$ & $\begin{array}{l}\mathrm{CBR}=0.452 \mathrm{G}-1.972 \mathrm{OMC}-0.222 \mathrm{~F}+ \\
48.583\end{array}$ & 0.872 & 0.761 \\
\hline $\begin{array}{c}\text { Model } \\
3\end{array}$ & $\begin{array}{l}\mathrm{CBR}=0.537 \mathrm{G}-3.211 \mathrm{OMC}-0.174 \mathrm{~F}- \\
31.493 \mathrm{MDD}+119.757\end{array}$ & 0.876 & 0.768 \\
\hline $\begin{array}{c}\text { Model } \\
4 \\
\end{array}$ & $\begin{array}{l}\mathrm{CBR}=0.570 \mathrm{G}-2.588 \mathrm{OMC}-0.108 \mathrm{~F}- \\
25.306 \mathrm{MDD}-0.296 \mathrm{LL}+105.940\end{array}$ & 0.878 & 0.771 \\
\hline $\begin{array}{c}\text { Model } \\
5\end{array}$ & $\begin{array}{l}\mathrm{CBR}=0.524 \mathrm{G}-2.689 \mathrm{OMC}-0.139 \mathrm{~F}- \\
19.206 \mathrm{MDD}+0.366 \mathrm{LL}-0.746 \mathrm{IP}+ \\
86.116\end{array}$ & 0.880 & 0.775 \\
\hline $\begin{array}{c}\text { Model } \\
6\end{array}$ & $\begin{array}{l}\mathrm{CBR}=0.524 \mathrm{G}-2.689 \mathrm{OMC}-0.139 \mathrm{~F}- \\
19.206 \mathrm{MDD}+0.366 \mathrm{LL}-0.746 \mathrm{IP}+0 \mathrm{LP}+ \\
86.116\end{array}$ & 0.880 & 0.775 \\
\hline $\begin{array}{l}\text { Model } \\
7\end{array}$ & $\begin{array}{l}\mathrm{CBR}=0.681 \mathrm{G}-2.917 \mathrm{OMC}+0.032 \mathrm{~F}- \\
17.991 \mathrm{MDD}+0.510 \mathrm{LL}-0.820 \mathrm{IP}+0 \mathrm{LP}+ \\
0.205 \mathrm{~S}+64.890\end{array}$ & 0.881 & 0.776 \\
\hline $\begin{array}{c}\text { Model } \\
8\end{array}$ & $\begin{array}{l}\mathrm{CBR}=0.524 \mathrm{G}-2.794 \mathrm{OMC}+0.056 \mathrm{LP}+ \\
45.657\end{array}$ & 0.862 & 0.744 \\
\hline
\end{tabular}

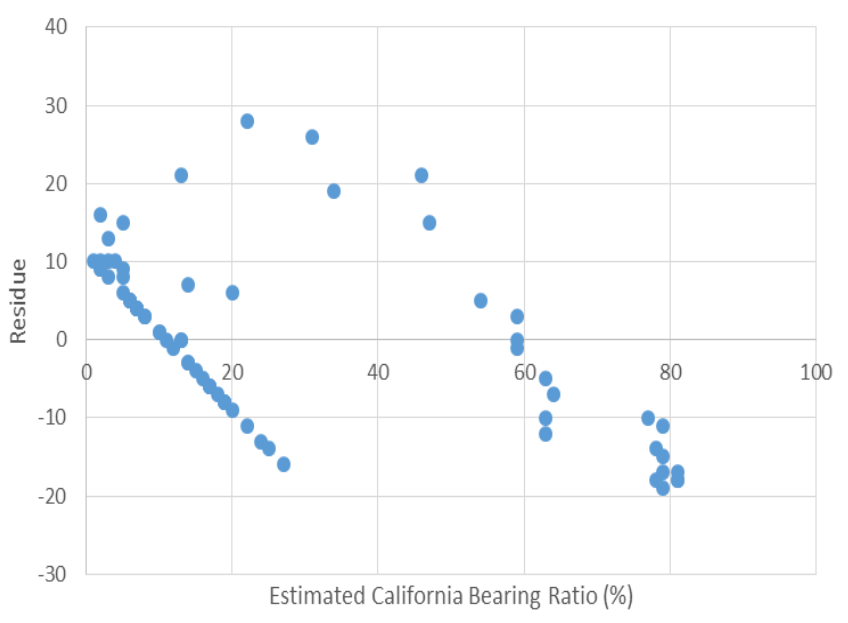

Fig. 4. Residue Analysis of SLRA model 1 (Gravel content).

Using the data of this research, errors from estimated CBR values were plotted in Figure 7. It can be observed that the proposed model 7 has the lowest error, followed by Kumar equation [4]. Therefore it can be said that the proposed model is acceptable.

However, the authors consider that this research does not limit the possibility of proposing other models of more complex correlation. It has been noted that a linear, single or multiple model will have many limitations and more complex models of correlation, based on the nonlinear relationship of the parameters evaluated that must be developed. In addition, a consideration of the influence of consistency Limits values and the content of fines $(\mathrm{F})$ in the soil needs to be studied.

Multiple linear correlation seems to be the most appropriate one for a range of $0-20$ in CBR values (finegrained soils), while thicker soils will be necessary to use more complex models.

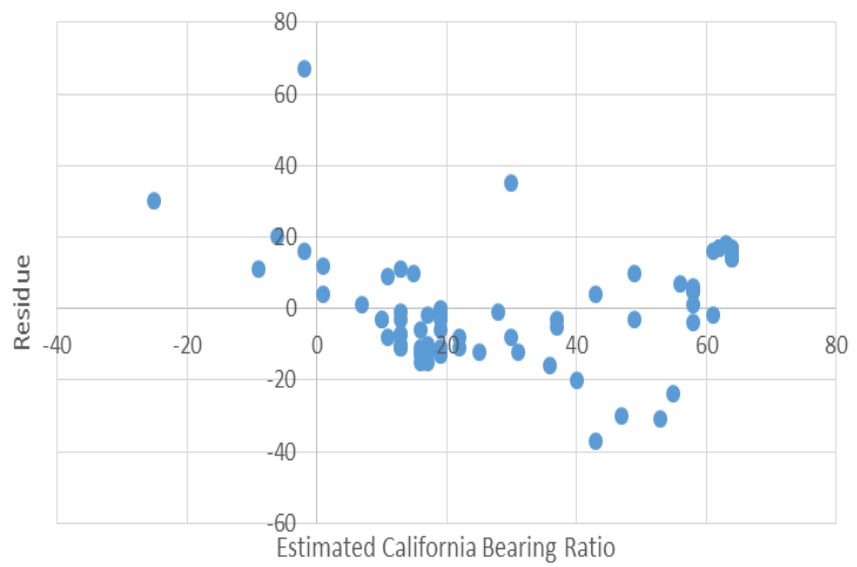

Fig. 5. Residue Analysis of SLRA model 8 (Optimum Moisture Content).

$14^{\text {th }}$ LACCEI International Multi-Conference for Engineering, Education and Technology: "Engineering Innovations for Global Sustainability" 
TABLE IV

PROPOSED MODELS FROM DIFFERENT RESEARCHES

\begin{tabular}{|c|c|c|c|}
\hline Research & Consideration & Model & $\begin{array}{l}\text { Statistical } \\
\text { Parameter }\end{array}$ \\
\hline $\begin{array}{l}\text { AASHTO } \\
(2002)\end{array}$ & $\begin{array}{l}\text { Granular with } \\
\text { fine soil }\end{array}$ & $\begin{array}{c}\mathrm{CBR}=75 / \\
\left(1+0.728\left(\mathrm{P}_{200} * \mathrm{IP}\right)\right)\end{array}$ & - \\
\hline $\begin{array}{l}\text { Patel y Desai } \\
(2010)\end{array}$ & Fine soil & $\begin{array}{c}\text { CBR (soaked) }=43.907 \\
-0.093(\text { IP) }-18.78 \\
(\mathrm{MDD})-0.3081(\mathrm{OMC}) \\
\end{array}$ & - \\
\hline $\begin{array}{l}\text { Saklecha et al } \\
\text { (2011) }\end{array}$ & $\mathrm{CBR}=1-70 \%$ & $\begin{array}{c}\text { CBR }=0.62 \text { OMC }+ \\
58.9 \mathrm{MDD}+0.11 \mathrm{LL}+ \\
0.53 \mathrm{LP}-126.18\end{array}$ & $\mathrm{R}=0.80$ \\
\hline $\begin{array}{l}\text { Yildirim y } \\
\text { Gunaydin } \\
\text { (2011) }\end{array}$ & $\begin{array}{l}\text { Granular and } \\
\text { fine soil }\end{array}$ & $\begin{array}{c}\mathrm{CBR}=0.22 \mathrm{G}+0.045 \mathrm{~S}+ \\
4.739 \mathrm{MDD}+ \\
0.122 \mathrm{OMC}\end{array}$ & $\mathrm{R}^{2}=0.88$ \\
\hline $\begin{array}{l}\text { Ramasubbara } \\
\text { o y Siva } \\
\text { (2013) }\end{array}$ & $\begin{array}{c}\text { Fine soil } \\
\text { CL, CH } \\
\text { CBR }=0.8-6 \%\end{array}$ & $\begin{array}{c}\text { CBR }(\text { soaked })= \\
0.064 \mathrm{~F}+0.082 \mathrm{~S}+0.033 \mathrm{G}- \\
0.069 \mathrm{LL}+0.157 \mathrm{LP}- \\
\text { 1.810MDD-0.061OMC }\end{array}$ & $\mathrm{R}^{2}=0.92$ \\
\hline $\begin{array}{l}\text { Kumar } \\
(2014)\end{array}$ & $\begin{array}{l}\text { Fine soil } \\
\text { ML } \\
\text { CBR }=5-7 \%\end{array}$ & $\begin{array}{c}\text { CBR (soaked) }= \\
0.127(\mathrm{LL})+0.00(\mathrm{LP})- \\
0.1598(\mathrm{PI})+ \\
1.405(\mathrm{MDD})- \\
0.259(\mathrm{OMC})+4.618\end{array}$ & - \\
\hline $\begin{array}{l}\text { Proposed } \\
\text { Model (2014) }\end{array}$ & $\begin{array}{l}\text { All type of } \\
\text { soil }\end{array}$ & $\begin{array}{c}\mathrm{CBR}=0.681 \mathrm{G}- \\
2.917 \mathrm{OMC}+0.032 \mathrm{~F}- \\
17.991 \mathrm{MDD}+0.510 \mathrm{LL} \\
-0.820 \mathrm{IP}+0.205 \mathrm{~S}+ \\
64.89\end{array}$ & $\mathrm{R}=0.89$ \\
\hline
\end{tabular}

The dispersion data for CBR values greater than 20 in residue analysis indicate that there are other parameters that influence in CBR that are not being considered in this research.

\section{CONCLUSIONS}

The relationship between the $\mathrm{CBR}$ and the physical parameters of the soil is not always linear in a wide range. In some cases, potential or exponential relationship is a better approximation, according to the evaluated parameter $(\% \mathrm{~F}, \mathrm{LL}$, LP, IP).

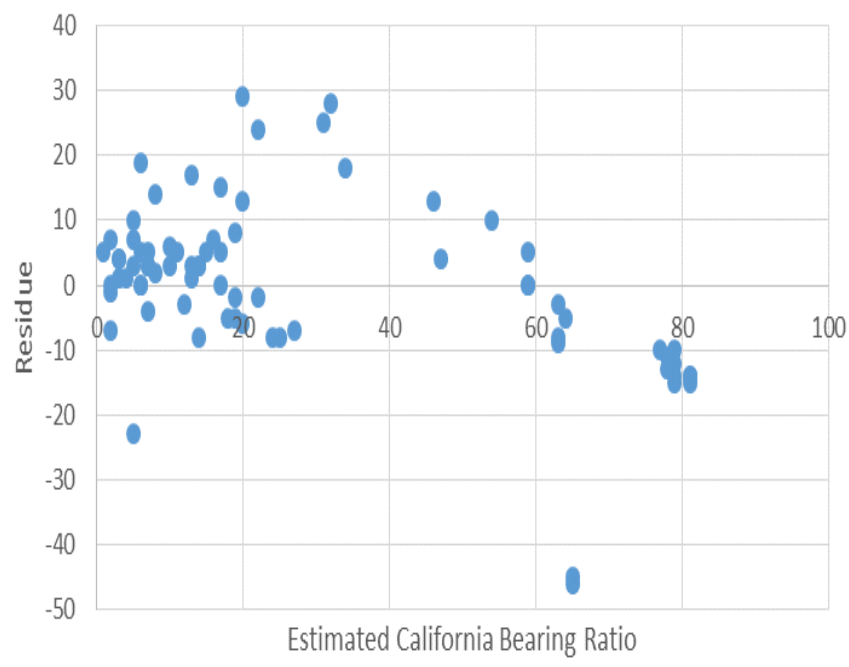

Fig. 6. Residue Analysis of Model 7 MLRA

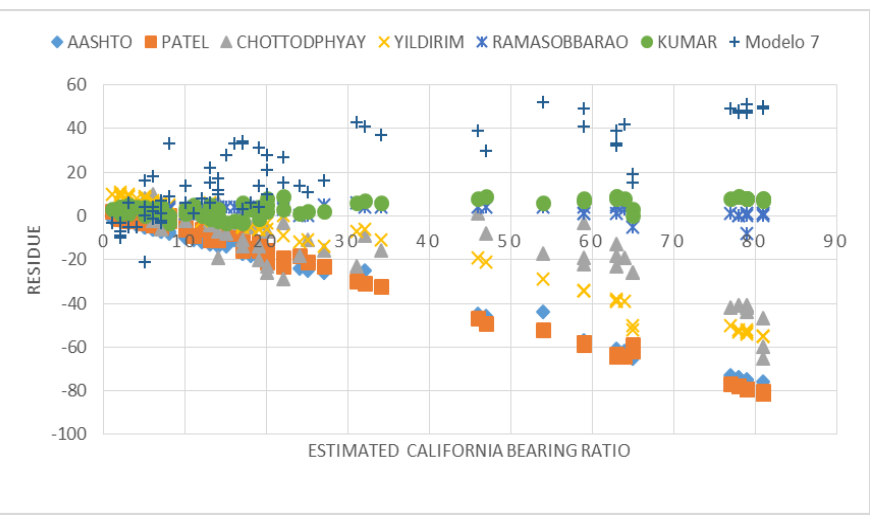

Fig. 7: Comparison between CBR values obtained from equation of different researchers

The most influential parameters in the CBR are the \% G, OMC, MDD, and $\% \mathrm{~F}$ as shown by their $\mathrm{R}$ of $0.84,0.81,0.76$, 0.74 , and 0.60 respectively. The least influential are the IP, LP, $\% \mathrm{~S}$ with an $\mathrm{R}$ of $0.53,0.45$ and 0.12 respectively.

The CBR is not dependent on a single parameter, but if on a combination of several of them, especially in short ranges. This poses two conditions: a multiple correlation model always reflects the value of CBR better than that of a simple correlation one. And correlation models should be proposed by soil type.

In this research, the model 7 that considers all soil parameters (\% G, OMC, MDD, \% F, LL, IP, LP, \% S) was the best correlation lineal model $(\mathrm{R}=0.881)$.

Results suggest considering a wide range of the databases to develop one or more complex models of correlation between soil parameters and the CBR, considering the relationship between these parameters, their influence on the behavior, the type and nature of the soil.

This result reveals that these SLRA models are not adequate for estimating CBR values.

MLRA models can be useful in soils of fine grain soils.

\section{ACKNOWLEDGMENT}

This work was made possible by Laboratory Testing of Construction Materials at Universidad de Piura where the historical data was taken.

\section{REFERENCES}

[1] AASHTO (2009). Standard method of test for California bearing ratio of laboratory compacted soils. ASTM D1883-07.

[2] ARAUJO, W. (2014). Ecuaciones de correlación del CBR con propiedades índices de suelo para la ciudad de Piura (Undergraduated thesis). Universidad de Piura, Piura, Peru.

[3] CHOTTOPADHYAY, B and T. DATTA. (2011). Correlation between CBR and index properties of soil. Proceedings of Indian Geotechnical Conference. India. Paper $\mathrm{N}^{\circ} \mathrm{A}-350$.

[4] KUMAR, D. (2014). A study of correlation between California Bearing Ratio Value (CBR) with other properties of soil. International Journal of Emerging Technology and Advanced Engineering. India. Vol. 04, Issue.

$14^{\text {th }}$ LACCEI International Multi-Conference for Engineering, Education and Technology: "Engineering Innovations for Global Sustainability" 
[5] PATEL, R. y M. DESAI. (2010). CBR Predicted by index properties for alluvial soils of South Gujarat. Indian Geotechnical Conference, Proc. IGC, Vol. 39, N¹, 79-82.

[6] RAMASUBBARAO, G y G. SIVA. (2013). Predicting soaked CBR value of fine grained soils using index and compaction characteristics. Jordan Journal of Civil Engineering. India. Vol. 7, $\mathrm{N}^{\circ} .3$.

[7] TASKIRAN, T. (2010). Prediction of California bearing ratio (CBR) of fine grained soils by AI methods. Advances in Engineering Software. Turkey, pp. 886-892.
[8] YILDIRIM, B. and O. GUNAYDIM. (2011). Estimation of California bearing ratio by using soft computing systems. Expert systems with applications. Turkey, pp. 6381-6391.

[9] SANCHEZ, F. (2012, 9 th april). Blog de conceptos y aplicaciones de la tecnología Ramcones en suelos y mezclas asfálticas. Tres formas de diseñar un suelo compactado, ventajas y desventajas. Available in: http://blogramcodes.blogspot.com/tres-formas-de-disenar-un-suelo.html

[10]BASSET, E. et al (1986). Statistics: Problems and Solutions. London: Edward Arnold. 2 edition. Residue Analysis. pp. 169-183.

$14^{\text {th }}$ LACCEI International Multi-Conference for Engineering, Education and Technology: "Engineering Innovations for Global Sustainability" 